\title{
GAMBARAN HISTOPATOLOGI HATI MENCIT SWISS YANG DIBERI AIR REBUSAN SARANG SEMUT (Mymercodia pendans) PASKA INDUKSI DENGAN CARBON TETRACHLORIDA $\left(\mathrm{CCl}_{4}\right)$
}

\author{
${ }^{1}$ Patricia Tatukude \\ ${ }^{2}$ Lily Loho \\ ${ }^{2}$ Poppy Lintong
}

\author{
${ }^{1}$ Kandidat Skripsi Fakultas Kedokteran Universitas Sam Ratulangi Manado \\ ${ }^{2}$ Bagian Patologi Anatomi Fakultas Kedokteran Universitas Sam Ratulangi Manado \\ Email: Patriciatatukude@rocketmail.com
}

\begin{abstract}
Abstrak: Dewasa ini tanaman sarang semut ${ }^{1}$ (Myrmecodia pendans) yang dianggap mampu mengatasi berbagai penyakit seperti kanker, asam urat, liver, stroke, jantung, wasir, nyeri punggung, alergi, sebagai tonikum hingga meningkatkan gairah seksual, sudah banyak dipublikasikan. Berdasarkan hasil uji penapisan kimia, tanaman sarang semut mengandung senyawa kimia golongan flavonoid dan tanin. Flavonoid merupakan antioksidan alam yang mampu bertindak sebagai pereduksi radikal hidroksil, superoksida dan radikal peroksil. Selain itu juga mengandung 313 ppm tokoferol yang meredam 96\% radikal bebas pada konsentrasi 12 ppm. Persentase inhibisi ini tetap konstan sampai pada konsentrasi yang lebih tinggi. Penelitian ini bertujuan untuk mengetahui gambaran histopatologi hati mencit swiss yang diberikan rebusan Myrmecodia pendans, setelah mencit tersebut diinduksi dengan $\mathrm{CCl}_{4}$. Penelitian yang dilakukan ini merupakan penelitian eksperimental laboratorik dengan rancangan acak lengkap (RAL). Dipakai 20 ekor mencit jantan (Swiss webster) dibagi dalam 4 kelompok percobaan yaitu A, B, C, dan D. Masing-masing kelompok terdiri dari 5 mencit. Mencit diberi pellet dan diinduksi karbon tetraklorida selama 5 hari. Pada hari ke-6, di beri rebusan sarang semut dosis 0,24cc/hari dan 0,48 cc/hari. Terminasi dilakukan 2 kali (masing-masing di bagi 2 mencit dalam 1 kali terminasi). Hasil dari penelitian ini tikus-tikus yang sudah diinduksi dengan $\mathrm{CCl}_{4}$ menunjukkan sel-sel hati steatosis dan nekrosis, namun setelah di berikan sarang semut mengalami regenerasi sel dengan tingkat maturasi lebih banyak dibandingkan hanya diberikan pellet saja. Simpulan: Pemberian sarang semut dengan dosis $0.24 \mathrm{cc} /$ hari selama 10 dan 14 hari menunjukkan regenerasi sel-sel hati pada kerusakan sel hati yang diinduksi dengan $\mathrm{CCl}_{4}$. Sedangkan pemberian rebusan sarang semut dengan dosis $0.48 \mathrm{cc} / \mathrm{hari}$ selama 14 hari ditemukan adanya sel radang dan perlemakan hati.
\end{abstract}

Kata kunci: tanaman sarang semut, carbon tetrachlorida, peradangan hati, perlemakan hati, nekrosis hati.

Abstract: Currently, many popular publication of sarang semut plants (Myrmecodia pendans) assumed can treat diseases includes : cancer, uric acid, liver, stroke, heart diseases, low back pain, allergic, as a tonic to increased libido. Based on chemical filtering test, known that sarang semut plants contains flavonoid and tannin. Flavonoid as a natural antioxidant that can act as hydroxyl radical pre reduction, super oxide, and peroxyl radical. In addition to contains 313 ppm tocopherol that transverse 95\% free radical in $12 \mathrm{ppm}$ concentration. Percentage of its inhibition constantly to highest consentration. This study aims to describe the liver histopathology swiss Webster given by Myrmecodia pendans stew, after the mice were induced with CCl4. This research is an experimental research laboratory with a completely randomized design (CRD). A total of 20 male mice (Swiss Webster) were divided into 4 experimental groups (A, B, C, D). Each group consisted of 5 mice. Mice were given pellets and induction by carbon tetrachloride for 5 days. On the 6th day, given Myrmecodia pendans stew with dose of 
0.24 сc / day and 0,48cc / day. Termination is done 2 times (each for 2 mice in one time termination). From the results, sarang semut stew (Mymercodia pendans) is able to repair damaged liver cells, although the mechanism of this still unknown. Generally, Mymercodia pendans believed to stimulate the proliferation of the liver cells and simultaneously neutralize free radicals produced by $\mathrm{CCl} 4$ that cause of liver cells demaged. Conclusion: Administration of sarang semut with dose of $0.24 \mathrm{cc} /$ day for 10 and 14 days give effect to protect the liver and improve the process of liver cell damage. While giving sarang semut stew with dose of $0.48 \mathrm{cc} /$ day for 14 days was found the presence of inflammatory cells and fatty liver.

Keywords: sarang semut plants, carbon tetrachlorida, liver cell inflammation, fatty liver, necrosis liver.

Dalam dunia kesehatan banyak dihasilkan berbagai macam obat dan kebanyakan yang diproduksi adalah obat sintetik. Dewasa ini penggunaan obat-obat sintetik beralih ke obat-obatan tradisional melalui pemanfaatan tanaman berkhasiat obat. Salah satu tanaman yang potensial sebagai tanaman obat adalah tanaman sarang semut (Myrmecodia pendens), merupakan tanaman epifit yang tumbuh menumpang pada tanaman inang. Secara empiris tanaman ini berkhasiat sebagai anti tumor, anti kanker, diabetes dan sebagainya. ${ }^{1}$

Tanaman sarang semut (Myrmecodia pendans) yang dianggap mampu mengatasi berbagai penyakit seperti kanker, asam urat, liver, stroke, jantung, wasir (ambien), nyeri punggung, alergi, sebagai tonikum hingga meningkatkan gairah seksual. ${ }^{1}$ Berdasarkan hasil uji penapisan kimia, diketahui tanaman sarang semut mengandung senyawa kimia golongan flavonoid dan tanin. Flavonoid merupakan antioksidan alam yang mampu bertindak sebagai pereduksi radikal hidroksil, superoksida dan radikal peroksil. Selain itu juga mengandung 313 ppm tokoferol yang meredam $96 \%$ radikal bebas pada konsentrasi 12 ppm. Persentase inhibisi ini tetap konstan sampai pada konsentrasi yang lebih tinggi. Mengingat telah beredarnya produk sarang semut di pasaran dan masih jarangnya publikasi ilmiah dari tanaman ini, maka peneliti terdorong untuk melakukan penelitian tanaman ini terhadap gambaran histopatologi hati mencit yang di rusakkan melalui induksi dengan Carbon tetrachlorida $\left(\mathrm{CCL}_{4}\right)^{2,3}$

Carbon tetrachlorida merupakan bahan kimia yang bersifat toksik. Zat ini bisa ditemukan pada makanan maupun minuman yang dalam dosis tertentu dapat menyebabkan kerusakan pada organ. Salah satu organ yang bisa mengalami kerusakan karena induksi $\mathrm{CCl}_{4}$ adalah hati. Senyawa $\mathrm{CCl}_{4}$ dapat menimbulkan kerusakan pada hati, berupa degenerasi maupun nekrosis. ${ }^{4}$ Tahap awal kerusakan pada sel hati berupa degenerasi hidrofik, kemudian berlanjut menjadi degenerasi lemak, sebelum akhirnya sel tersebut mengalami kematian atau nekrosis. Penelitian yang dilakukan oleh Soni et al., (2008) melaporkan bahwa tikus percobaan yang diberikan $\mathrm{CCl}_{4}$ dengan dosis $0,05 \mathrm{ml} / \mathrm{kg}$ bobot badan mampu merusak selsel hati sehingga mengalami degenerasi hidropik, lemak dan nekrosis. ${ }^{5}$

Tujuan Penelitian ini adalah Untuk mengetahui gambaran histopatologi hati mencit swiss yang diberikan rebusan Myrmecodia pendans, setelah mencit tersebut diinduksi dengan $\mathrm{CCl}_{4}$.

\section{METODE}

Penelitian yang dilakukan ini merupakan penelitian eksperimental laboratorik dengan rancangan acak lengkap (RAL). Penelitian ini dilakukan di laboratorium Patologi Anatomi Fakultas kedokteran Universitas Sam Ratulangi Manado. Populasi penelitian ini adalah 20 ekor mencit jantan (Swiss webster), berumur 12 minggu dengan berat badan 2025 gram dibagi dalam 4 kelompok percobaan yaitu kelompok A, B, C, dan D. Masingmasing kelompok terdiri dari 5 mencit.

Dosis tanaman sarang semut yang di gunakan 200 gram direbus dalam 5 gelas air (1 gelas=200 ml). Setelah tanaman sarang semut di rebus maka air yang tersisa rata-rata 
$600 \mathrm{ml}$ semua harus di habiskan untuk orang dewasa. Jika dosis tanaman sarang semut yang di berikan pada orang dewasa dengan berat rata-rata $50 \mathrm{~kg}$ adalah $600 \mathrm{ml}$ per hari. Mencit yang beratnya $20 \mathrm{gr}$, dosisnya adalah (20/50000) $\times 600$ сс $=$
0,24 cc/gr/bb/hari. Tanaman sarang semut direbus setiap hari.Air rebusan sarang semut diberikan pada mencit dilakukan secara oral dengan menggunakan NGT pediatric no: 3,5 yang disambungkan dengan disposable.

Tabel 1. Gambaran makroskopik hati mencit

\begin{tabular}{|c|c|c|c|c|c|c|c|}
\hline \multicolumn{2}{|c|}{$\begin{array}{l}\text { Kelompok } \\
\text { Hewan Uji }\end{array}$} & Warna & Konsistensi & $\begin{array}{l}\text { Berat } \\
\text { (gr) }\end{array}$ & $\begin{array}{l}\text { Panjang } \\
\text { (cm) }\end{array}$ & $\begin{array}{l}\text { Lebar } \\
(\mathrm{cm})\end{array}$ & $\begin{array}{l}\text { Tinggi } \\
\text { (cm) }\end{array}$ \\
\hline Kontrol & A & Merah & Kenyal & 1,03 & 1,7 & 2 & 1,1 \\
\hline $\mathrm{CCL}_{4}$ & B & $\begin{array}{c}\text { Cokelat } \\
\text { Kekuningan }\end{array}$ & Kenyal & 1,01 & 1,4 & 1,8 & 1,0 \\
\hline $\mathrm{CCL}_{4}$ & $\mathrm{C}_{1}$ & $\begin{array}{c}\text { Cokelat } \\
\text { Kekuningan }\end{array}$ & Kenyal & 1 & 1,3 & 1,65 & 1,0 \\
\hline $\mathrm{CCL}_{4}$ & $\mathrm{C}_{2}$ & Merah & Kenyal & 1,4 & 2 & 2 & 0,8 \\
\hline $\begin{array}{c}\mathrm{CCL}_{4}+ \\
\text { Mycordia } \\
\text { Pendans } \\
\end{array}$ & $\mathrm{D}_{1}$ & Merah & Kenyal & 1,21 & 1,8 & 1,7 & 1 \\
\hline $\begin{array}{c}\mathrm{CCl}_{4}+ \\
\text { Mycordia } \\
\text { Pendans }\end{array}$ & $\mathrm{D}_{2}$ & $\begin{array}{c}\text { Merah } \\
\text { Kecokelatan }\end{array}$ & Kenyal & 1,05 & 1,7 & 1,7 & 0.6 \\
\hline $\begin{array}{c}\mathrm{CCl}_{4}+ \\
\text { Mycordia } \\
\text { Pendans } \\
\end{array}$ & $\mathrm{E}_{1}$ & Merah & Kenyal & 1,15 & 2 & 1,7 & 1,1 \\
\hline $\begin{array}{c}\mathrm{CCL}_{4}+ \\
\text { Mycordia } \\
\text { Pendans }\end{array}$ & $\mathrm{E}_{2}$ & $\begin{array}{c}\text { Merah } \\
\text { Kekuningan }\end{array}$ & Kenyal & 0,88 & 1,9 & 1,6 & 0,5 \\
\hline
\end{tabular}

\section{HASIL DAN BAHASAN}

\section{Gambaran makroskopik}

Pengamatan secara makroskopik dimulai pada saat otopsi dilakukan dan diperoleh data mengenai warna, konsistensi, berat dan ukuran dari hati. Gambaran makroskopik hati kelompok perlakukan memperlihatkan warna yang lebih terang dibandingkan dengan kelompok kontrol. Konsistensi hati sama yaitu kenyal sedangkan berat dan ukuran bervariasi antara satu kelompok dan kelompok lainnya.

\section{Gambaran mikroskopik}

Mencit kelompok A (kontrol negatif) didapatkan gambaran hati yang normal. (Gambar 1)

Pada kelompok B perlakuan tikus diberikan $\mathrm{CCl}_{4}$. Tikus diberikan pelet ditambah $\mathrm{CCl}_{4}$ dengan konsentrasi $0.05 \mathrm{ml}$ selama tiga hari berturut-turut, secara mikroskopik menunjukkan steatosis dan nekrosis, dan sel-sel radang (Gambar 2).

Pada kelompok $\mathrm{C}$ yang merupakan kelompok perlakuan yang diberikan $\mathrm{CCL}_{4}$ dan di lanjutkan pemberian pelet pada hari ke-6 kemudian diterminasi pada hari ke-10 (C1) dan kelompok C2 yang diterminasi pada hari ke-14 memperlihatkan regenerasi sel-sel hati secara difus ditandai sel besar, inti besar, beberapa dengan inti ganda. Beberapa sel-sel hati dengan steatosis masih terlihat (Gambar 3). Tampak proses perlemakan hati (gambar 4) dan regenerasi sel hati (Gambar 5). Pada kelompok perlakuan $\mathrm{C} 2$ yang diberikan $\mathrm{CCl}_{4}$ dan dilanjutkan pemberian pellet kemudian diterminasi hari ke-14 tampak regenerasi selsel hati, namun masih ada steatosis dan ada fokus sel radang (Gambar 6).

Kelompok D adalah kelompok perlakukan yang diberikan CCl4 selama 5 hari, 
tetapi pada hari ke 6 dilanjutkan dengan pemberian Myrmecodia pendans dengan dosis $0.24 \mathrm{cc} /$ hari. umumnya sel-sel hati degenerasi, maturisasi lebih banyak(kurang sel besar), kongesti berkurang tapi masih ada, tingkat maturisasi lebih baik, dan sitoplasma lebih homogen terutama di daerah vena sentralis gambar kanan. (Gambar 7 dan 8).

Sel hati yang mendapatkan perlakuan CCl4 selama lima hari dilanjutkan pada hari ke-6 selama 9 hari diberikan Myrmecodia pendans $0,48 \mathrm{cc} /$ hari yang kemudian diterminasi hari ke-14 (Gambar 9).

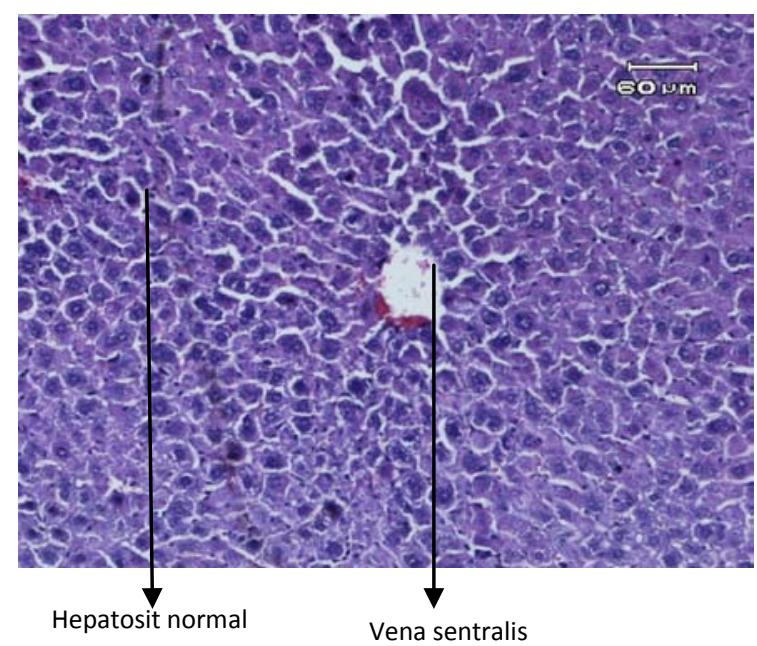

Gambar 1. Struktur natı normaı paaa tıkus kontrol (kelompok A) pembesaran 100-200 x. Tampak vena sentralis dan gambaran hati normal.

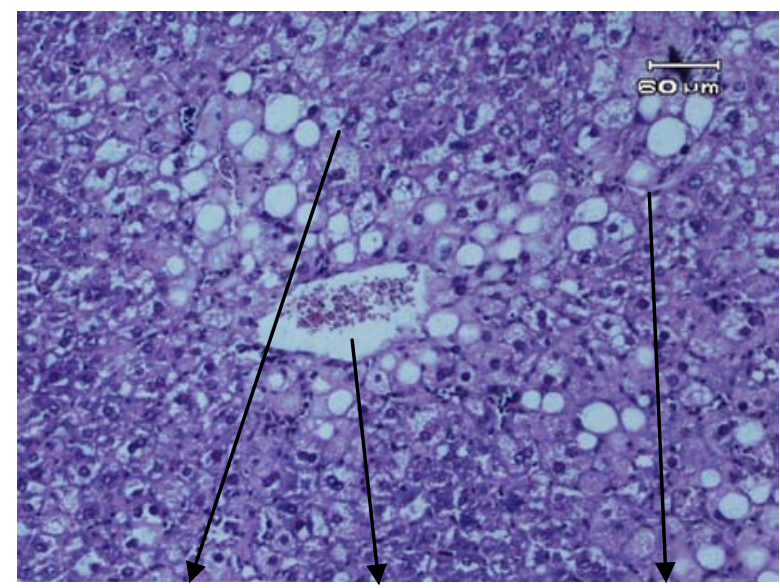

Makrovesikuler

Vena sentralis

Mikrovesikuler

Gambar 2. gambaran hati tikus yang diinduksi dengan $\mathrm{CCL}_{4}$ (kelompok B). Pada daerah sekitar vena sentralis: banyak perlemakan makrovesikuler dan mikrovesikuler, dan sebagian sel sudah nekrosis.

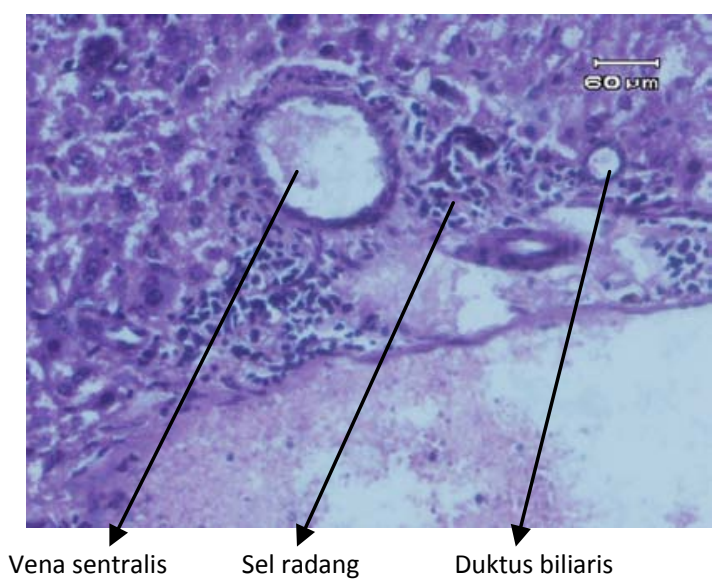

Gambar 3. Gambaran hati mencit yang diberikan pelet ditambah dengan $\mathrm{CCl}_{4} \quad 0.05 \mathrm{ml}$ selama 5 hari dilanjutkan dengan pemberian pellet sampai hari ke-14 tampak banyak sel-sel radang, V. sentralis melebar dan perlemakan makrovesikuler. (Kelompok C1)

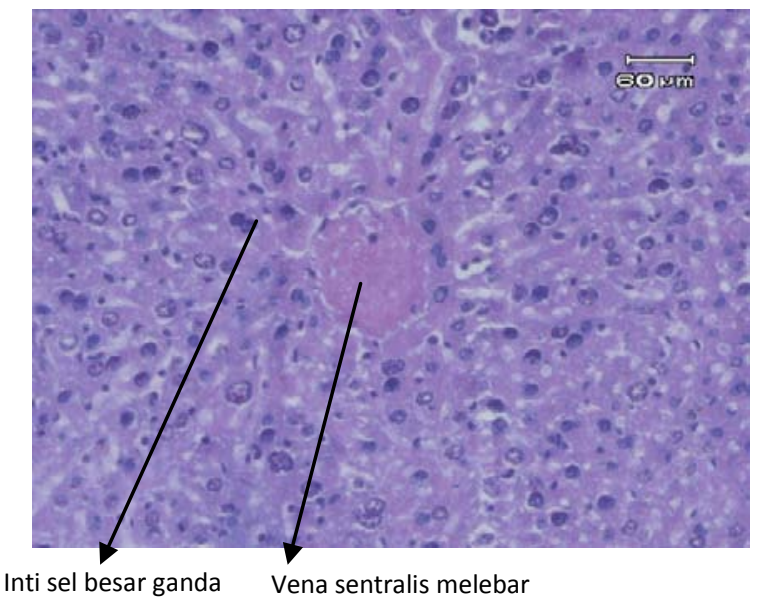

Gambar 4. Gambaran hati mencit yang diberikan pelet ditambah dengan $\mathrm{CCl}_{4} 0.05 \mathrm{ml}$ selama 5 hari dilanjutkan dengan pemberian pellet sampai hari ke-14 tampak regenerasi sel hati.

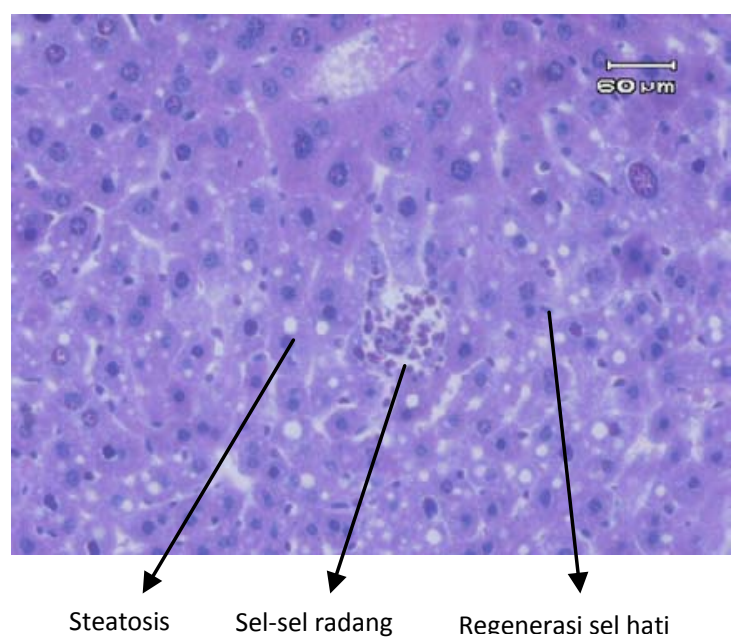

Gambar 5. Kelompok perlakuan C2 yang diberikan 
$\mathrm{Ccl}_{4}$ dan dilanjutkan pemberian pellet kemudian diterminasi hari ke-14 tampak regenerasi sel-sel hati, masih ada steatosis dan ada fokus sel radang (Kelompok C2)

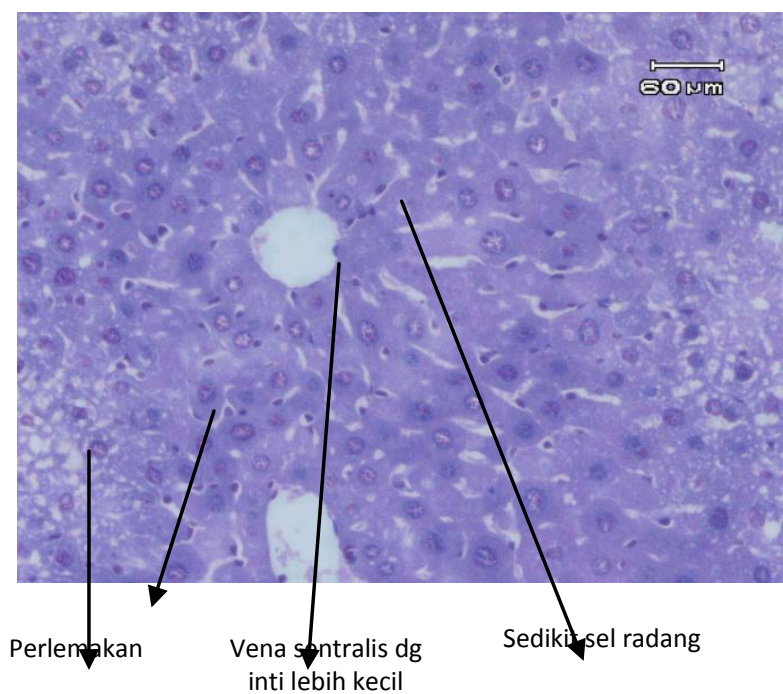

Gambar 6. Kelompok D1 adalah kelompok perlakukan yang diberikan CCl4 selama 5 hari, tetapi pada hari ke 6 dilanjutkan dengan pemberian myrmecodia pendans dengan dosis $0.24 \mathrm{cc} / \mathrm{hari}$. Tampak sedikit sel radang dan proses regenerasi sudah terjadi.

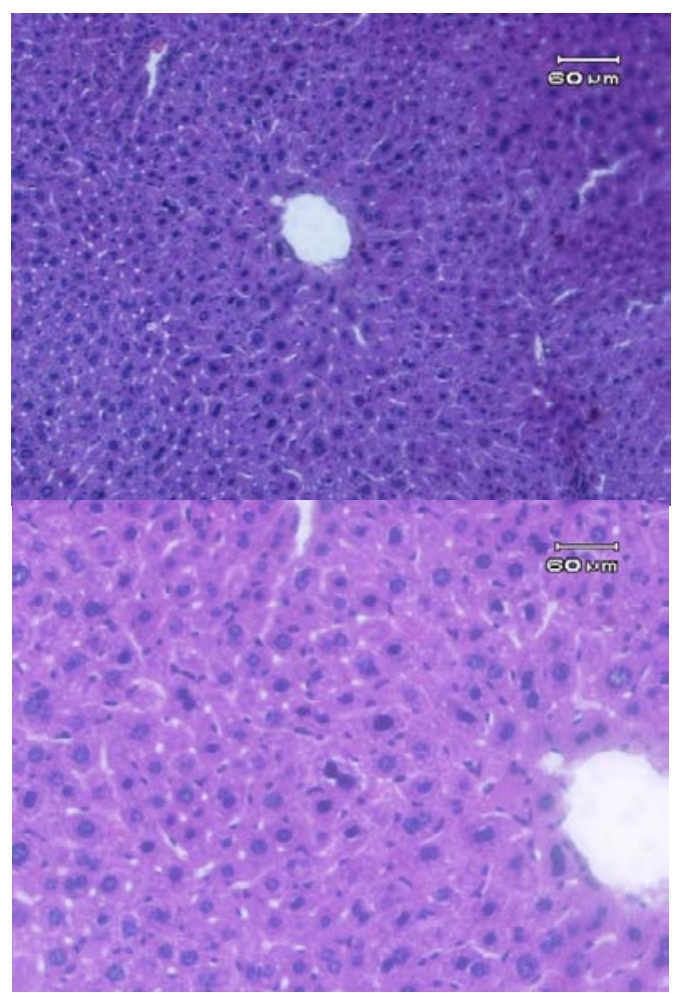

Gambar 7. Kelompok D2 sel-sel hati umumnya sudah regenerasi, maturisasi lebih banyak (kurang sel besar), kongesti berkurang. (gambar D2)

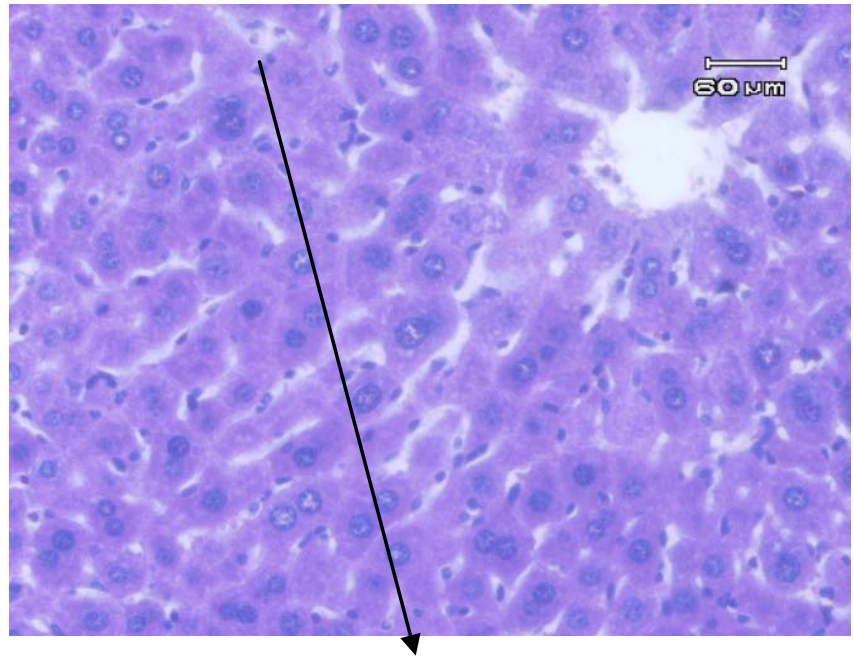

Fokus sel radang

Gambar 8. Kelompok E1 sampai pada hari ke-5 diberikan CCl4, pada hari ke-6 dan seterusnya diberikan pada myrmecodia pendans dengan dosis 0,48 cc/hari tampak sel-sel hati mengalami perlemakan difus.

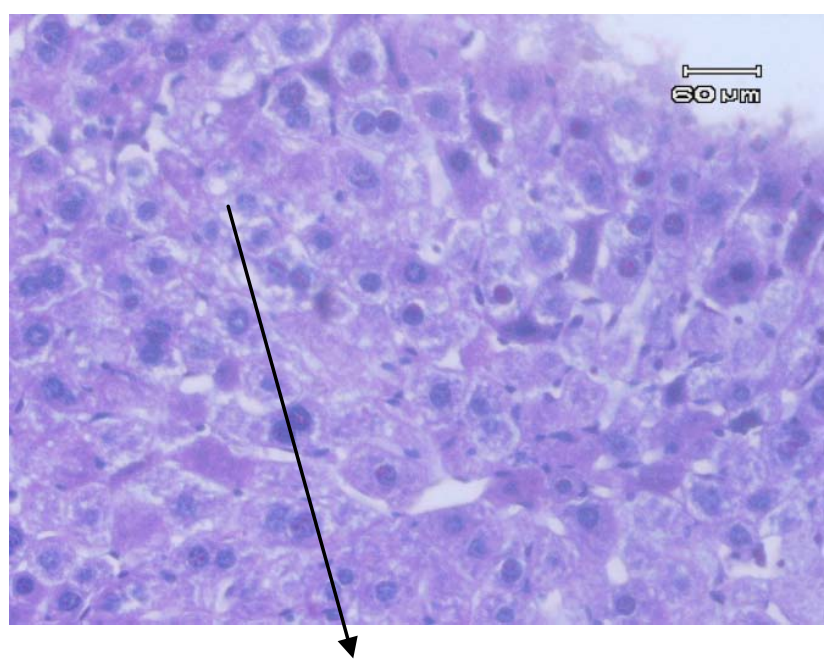

Sudah regenerasi tapi masih ada sisa perlemakan sedikit

Gambar 9. Sel hati yang mendapatkan perlakuan CCl4 selama lima hari dilanjutkan diberikan myrmecodia pendans $0,48 \mathrm{cc} / \mathrm{hari}$ yang kemudian diterminasi hari ke-14 menunjukkan regenerasi sel hati lebih baik (Kelompok E2).

\section{BAHASAN}

Hati rentan terkena bahan-bahan toksik, mikroba dan terhadap gangguan sirkulasi. Karbon tetraklorida merupakan salah satu zat toksik yang bisa menyebabkan kerusakan hati. Meskipun setelah cedera masa hati dapat pulih kembali dalam waktu beberapa minggu oleh proses regenerasi secara fisiologis. Berdasarkan hasil penelitian yang dilakukan 
oleh Arif Soeksmanto dkk, uji toksisitas akut ekstrak air tanaman sarang semut terhadap histologi organ hati tikus, mereka menemukan bahwa umumnya pemberian dosis ekstrak air tanaman sarang semut tidak menimbulkan kelainanan yang menyebabkan hewan sakit. Menurut Kaplowitz (2002) kerusakan sel-sel hati yang disebabkan oleh bahan toksik, umumnya meliputi partisipasi metabolit terhadap bahan toksik, selanjutnya akan mendatangkan respon imun, bahkan dapat langsung mempengaruhi biokimia sel. ${ }^{28}$ Terjadinya nekrosis sel hati ini, dapat diketahui dengan adanya perubahan pada sitoplasma dan inti selnya. ${ }^{29}$ ketika membran plasma sel hati rusak, berbagai enzim dan sitosol akan dilepas ke dalam darah dan ini dapat dijadikan penanda kuantitatif terhadap luas dan tipe kerusakan sel hati. ${ }^{30}$

Penelitian pada tikus ini dengan pemberian $\mathrm{CCl}_{4}$ dengan dosis $0,05 \mathrm{ml} / \mathrm{hari}$ telah memperlihatkan kerusakan sel-sel hati berupa peradangan, steatosis dan nekrosis(lihat gambar 8 dan 9) dibandingkan dengan tikus kontrol hati normal. . Dari hasil percobaan ini terlihat bahwa kelompok yang mendapatkan $\mathrm{CCL}_{4}$ mengalami steatosis. Stetosis merupakan gambaran patologi yang ditandai dengan akumulasi lemak di dalam sel hati yang disebabkan radikal bebas dari $\mathrm{CCl}_{4}$.

Kelompok D tikus yang diberi air rebusan sarang semut setelah pemberian $\mathrm{CCL}_{4}$ dihentikan menunjukkan regenerasi sel yang banyak dan sel hepatosit sudah mulai kembali normal (gambar 16). Hal ini mungkin berhubungan dengan kerja dari tanaman sarang semut sebagai hapatoprotektor. Flavanoid yang merupakan salah satu kandungan yang terdapat dalam tanaman sarang semut berfungsi sebagai anti oskidan dalam proses peroksidasi lipid. Sehingga tidak menganggu homeostasis $\mathrm{Ca}^{2+}$ dan tidak menimbulkan perlemakan sel hati.

Pada kelompok D2 ditemukan regenerasi sel hati sudah lebih baik, tidak ditemukan adanya perlemakan dan sel radang. Pada kelompok D2 diberikan CCl4 selama 5 hari dilanjutkan dengan pemberian rebusan sarang semut selama 14 hari dengan dosis $0.24 \mathrm{cc} / \mathrm{hari}$. Hal ini menunjukkan bahwa tanaman sarang semut memberikan pengaruh hepato protektor.

Pada kelompok E1 dengan pemberian $\mathrm{CCl}_{4}$ selama 5 hari dilanjutkan dengan pemberian rebusan sarang semut dengan dosis $0.48 \mathrm{cc} /$ hari selama 10 hari. Ditemukan sedikit sel radang dan regenerasi hati.

Pada kelompok E2 diberikan CCl4 selama 5 hari dilanjutkan dengan pemberian sarang semut dengan dosis $0.48 \mathrm{cc} / \mathrm{hari}$ selama 14 hari. ditemukan adanya regenerasi sel hati lebih baik. Beberapa faktor yang perlu dipertimbangkan dalam penggunaan air rebusan tanaman sarang semut ini adalah faktor farmakokinetik dan farmakodinamik zat berkhasiat yang terkandung di dalamnya. Farmakokinetik menyangkut absorpsi, distribusi, metabolisme, ekskresi dan biavailibiolitas zat tersebut dalam darah, sedangkan farmakodinamik menyangkut aksi obat dan efek yang ditimbulkan (efek samping atau efek toksik). Hal lainnya yang mungkin perlu diperhatikan adalah lama pemberian, jarak pemberian, individu yang mengkonsumsi, dan dosis yang diberikan. Batas keamanan (margin of safety) juga perlu diperhitungkan.

Dari hasil penelitian didapatkan sarang semut(Mymercodia pendans) mampu memperbaiki kerusakan sel hati, walaupun mekanisme perbaikan kerusakan sel-sel hati akibat pemberian Mymercodia pendans belum diketahui secara spesifik, secara umum Mymercodia pendans diyakini mampu merangsang proliferasi sel-sel hati yang baru dan sekaligus menetralisir radikal bebas yang dihasilkan oleh reaksi $\mathrm{ccl}_{4}$ yang merusak selsel hati. Hal ini terlihat pada penelitian ini tikus-tikus yang sudah diinduksi dengan $\mathrm{Ccl}_{4}$ menunjukkan sel-sel hati steatosis dan nekrosis, namun setelah di berikan sarang semut mengalami regenerasi sel dengan tingkat maturasi lebih dibandingkan hanya diberikan pellet saja.

Keterbatasan dari penelitian ini adalah belum adanya referensi yang cukup mengenai tanaman sarang semut, tidak adanya perhitungan yang jelas mengenai 
farmakokinetika tanaman sarang semut, dan jumlah sel regenerasi atau perlemakan per lapangan pandang tidak diukur secara kuantitatif. Namun, demikian, hasil penelitian ini menambah informasi dan pengetahuan mengenai efek positif dan negatif tanaman sarang semut terhadap kesehatan dan untuk mengembangkan penelitian-penelitian yang berhubungan dengan tanaman sarang semut.

\section{SIMPULAN DAN SARAN}

Berdasarkan hasil yang didapat dari penelitian ini maka dapat disimpulkan:

1. Pemberian $\mathrm{CCl}_{4}$ dosis $0,05 \mathrm{ml}$ selama 5 hari menyebabkan steatosis dan nekrosis sel hati serta sel-sel radang.

2. Pemberian air rebusan sarang semut dosis 0,24 cc/hari selama 10 hari menunjukkan regenerasi sel-sel hati dan selama 14 hari tingkat maturasi sel hati lebih baik.

3. Pemberian air rebusan sarang semut dosis 0,48 cc/hari selama 10 hari menimbulkan perlemakan hati secara difus namun pada hari ke 14 terlihat regenerasi sel hati, namun masih tampak steatosis.

4. Penelitian lebih lanjut dengan jumlah sampel yang lebih besar dan waktu follow up yang lebih lama diperlukan untuk mendapatkan hasil yang lebih akurat.

\section{DAFTAR PUSTAKA}

1. Subroto, M.A. \& Saputro, H. 2006. Gempur penyakit dengan sarang semut.Cetakan pertama, Penebar Swadaya Trubus no 438 edisi XXXVII (Mei 2006)

2. Huxley, C.R. 1993. The tuberosus epiphytes of the rubiaceae 6: A taxonomic history of the hydnophytinae. Blumea 37: 335- 340.

3. Harun N. \& Syari, W. 2002. Aktivitas antioksidan ekstrak daun dewa dalam menghambat sifat hepatotoksik halotan dengan dosis sub anastesi pada mencit. Jurnal Sains dan Teknologi Farmasi 7(2): 63-70.

4. Weber L, Boll M, Stampfl A. 2003. Hepatotoxicity and Mechanism of Action of Haloalkanes: Carbon Tetrachloride as a Toxicological Model. Critical Reviews in Toxicology 33:105-136.

5. Soni B, Visavadiya NP, Madamwar D. 2008 Ameliorative Action of Cyanobacterial Phycoerytri on CCl4-Induced Toxicity in Rats. Toxicology. 248: 59-65.

6. Guyton \&Hall. 2000. Fisiologi Kedokteran. Jakarta: EGC

7. Hebel R, Stromberg MW. Anatomy of the Laboratory Rat, The William \& Wilin Company, Baltimore 1989: 50.

8. Anonim. 2012. Polyphenols - Flavonoids stilbenoids - Phenolic Acid. International dition.

http://www.biolinks.co.jp/pdf/catalog_polyph enol_np_final\%5B1\%5D.pdf

9. Health To Day. 2006. Sarang semut dipercaya sebagai obat tradisional untuk anti kanker. http://sarangsemut.co.id/Health_Today_September_2006_ _Sarang_Semut_.pdf. 2 Maret 2012.

10. Gould K.S and C.Lister. 2006. Flavonoid functions in plants. Dalam Anderson Q.M and K.R Markham. 2006. Flavonoids : chemistry, Biochemistry and applications. CRC Press. New York. Pp. 397

11. Middleton E, C. Kandasmawi and T.C Theoharides. 2000. The effect of plant flavonoids on mammalian cells : implications for inflamations, heart desease and cancer. Pharmacological Review. Vol. 52(4) pp. 673 $-751$

12. Tim Cusnie T.P and A.J Lamb. 2005. Antimicrobial activity of flavonoids. International Journal of Antimicrobial Agents 26:343-353.

13. Tapas A.M, D.M Sakarkar and R.b Kakde. 2008. Flavonoids as Nutraceuticals : A Review. Tropical Journal of Pharmaceutical Research. 7(3):1089-1099.

14. Min B.R and S.P Hart. 2003. Tannis for suppression of internal parasites. Journal Animal Sciences. 81(E.suppl.2):E102 - E109.

15. Karou D, M.H Dicko, J. Simpore and A.S Traore. 2005. Atioxidant and antibcaterial activities of polyphenols fom ethnomedicinal plants of Burkina Faso. African Journal of Biotechnology. Vol. 4(8). Pp. 823-828.

16. Ito V.M, P.F Martins C.B Batistella and M.R Wolf Maciel. 2005. Tocopherols and Phytosterols concentration from soybean aol deodorizer distillate. 2nd Mercosur Congress on Chemical Engineering and 4th Mercosur Congress on Process Systems Engineering.

17. Guyton A, Hall J. Buku Ajar Fisiologi 
466 Jurnal e-Biomedik (eBM), Volume 2, Nomor 2, Juli 2014, hlm. 453-466

Kedokteran, EGC, Jakarta, 2002:11031107.

18. Brunner \& Suddarth. 2008. Textbook of medical surgical nursing, eleventh edition. Philadelpia: Lippincott William \& Wilkins

19. Arief, S. Radikal Bebas. Bagian Ilmu Kesehatan Anak FK Unair/ RS. Dr. Sutomo, Surabaya, 2006.

20. http://www.enpromer2005.eq.ufrj.br/nukle o/pdfs/0673_trabalho673_revisado.pdf

21. Keyman, Withfield. 2006. Dietary proteins intake in patients with hepatic encephalopahaty and chirrosis: current practice in NSW and ACT. Diakses pada tanggal 3 mei 2009 dari: http://www.healthsystem.virginia.edu/inter net/digestive-

22. Black \& Hawks. 2005. Medical surgical nursing: Clinical management for positive outcome. St.Louis : Elvier Saunders

23. Sudiono, J., Kurniadi, B., dan Henrawan, A., 2003, Ilmu Patologi, EGC, Ed. 1, Jakarta.
24. Sherlock, S,1995, Penyakit hati dan sistem saluran empedu, Widya Medika, Ed.2, Jakarta.

25. Rao GMM, Rao CV, Pushpangadan P, Shirwaikar A. J. Ethnopharmacol. 103 (2006) 484-490.

26. Day L, Shikuma C, Gerschenson M. Mithochondrion 4 (2004) 95-109.

27. Putz R, Pabst R,2007, Atlas anatomi manusia. EGC, Edisi 22. Jakarta. 142.

28. Kaplowitz, N. 2002. Biochemichal and celluler mechanisms of toxic liver injuri. Semin. Liver. Dis. 22:137-44.

29. Evans, J.G * W.H. Butler. 1993: Histopathology in Safty Evaluation. Dalam : Expe-rimental Toxicology. The Basic issues. $2^{\text {nd }}$ edition. D. Anderson and D.M. Conning (eds). Hartnolis Ltd. Bodmin.

30. Huxtable, C.R.R.1998. The urinary system. Dalam: Clinicopathologic Principles for Veterinary Medicine. First Published, W.F. Robinson \& C.R.R Huxtable (eds). Cambridge University Press, New York. 